\title{
Essential oil composition and variability of Thymus lotocephalus and Thymus $\times$ mourae
}

\section{Lígia R. Salgueiro ${ }^{\mathrm{a}, *}$, Roser Vila ${ }^{\mathrm{b}}$, Xavier Tomàs ${ }^{\mathrm{c}}$, Salvador Cañigueral ${ }^{\mathrm{b}}$, Jorge Paiva ${ }^{\mathrm{d}}$, António Proença da Cunha ${ }^{\mathrm{a}}$, Tomàs Adzet ${ }^{\mathrm{b}}$}

${ }^{a}$ Laboratório de Farmacognosia, Faculdade de Farmácia, Universidade de Coimbra, Rua do Norte, 3000 Coimbra, Portugal

${ }^{\mathrm{b}}$ Unitat de Farmacologia i Farmacognòsia, Facultat de Farmàcia, Universitat de Barcelona, Av. Diagonal, 643, E - 08028 Barcelona, Spain

${ }^{c}$ Departament de Quimiometria, Institut Quimic de Sarrià, E-08017 Barcelona, Spain

${ }^{\mathrm{d} I n s t i t u t o}$ Botânico, Universidade de Coimbra, 3000 Coimbra, Portugal

Received 11 February 1999; accepted 9 June 1999

\begin{abstract}
The composition of the essential oils of four populations of Thymus lotocephalus G. López and R. Morales and one population of T. $\times$ mourae Paiva and Salgueiro, two endemic taxa from Portugal, was investigated mainly by GC and GC-MS. $T \times$ mourae is a natural hybrid between T. lotocephalus and T. mastichina (L.) L. subsp. donyanae R. Morales, which essential oil was analysed for the first time. In its oil, it was possible to find compounds of both parents, which could enable us to confirm its intermediate status between those two taxa. 1,8-Cineole and borneol were the main constituents in the essential oil of $T . \times$ mourae, whereas linalool, geranyl acetate and 1,8-cineol were the major ones in $T$. lotocephalus. Intermedeol was also an important constituent in the oils of both taxa. Nevertheless, the volatile oils of the four populations investigated of $T$. lotocephalus showed important differences among the main constituents. In order to study their infraspecific variability, the results obtained in the analysis of individual plants were submitted to a Principal Component and Chemometric Cluster Analyses. Five types of essential oils were found: linalool, 1,8-cineole, linalool/1,8-cineole, linalyl acetate/linalool and geranyl acetate. (C) 2000 Elsevier Science Ltd. All rights reserved.
\end{abstract}

Keywords: Thymus lotocephalus; Thymus $\times$ mourae; Lamiaceae; Essential oils; GC-MS; Infraspecific variability

* Corresponding author. Tel.: + 351-39-410-9995; fax: + 351-39-827126. 


\section{Introduction}

The chemical polymorphism of Thymus essential oils is a widespread phenomenon (Stahl-Biskup, 1991). Several chemotypes of several Portuguese Thymus sp. have been previously identified by us, such as: T. zygis Loefl. ex L. subsp. sylvestris (Proença da Cunha and Salgueiro, 1991), T. zygis Loefl. ex L. subsp. zygis (Salgueiro et al., 1993), T. pulegioides L. (Salgueiro et al., 1993), T. capitellatus Hoffmanns. and Link (Salgueiro, 1992), T. carnosus Boiss (Salgueiro et al., 1995), T. villosus L. subsp. villosus (Salgueiro et al., 1997a), T. camphoratus Hoffmanns. and Link (Salgueiro et al., 1997b), T. mastichina L. (Salgueiro et al., 1997c), and T. albicans Hoffmanns. and Link (Salgueiro et al., 1997c). Continuing our research on the composition of the essential oils of Portuguese thymes, we now report on the composition and variability of the essential oil of two endemic taxa, T. lotocephalus G. López and R. Morales and T. $\times$ mourae Paiva and Salgueiro.

T. $\times$ mourae is a hybrid between T. lotochephalus and T. mastichina (L.) L. subsp. donyanae R. Morales. It is a very rare plant occurring in a restricted area of the Algarve (Quinta de Marim), which we have described in 1994 (Paiva and Salgueiro, 1994). So, the composition of its essential oil is presented here for the first time.

T. lotocephalus is an endemic and also a rare species from SE Algarve. Little information about the essential oil of this taxon was available but its infraspecific variability was not known yet. Salgueiro (1992) reported a large amount of 1,8-cineole, camphor, linalool, linalyl acetate and $\alpha$-pinene in the essential oil from a sample from Algarve, but more precise data were not given. Later, studies carried out by Figueiredo et al. (1993) on essential oils isolated from flowers, during full flowering, and from leaves, during the vegetative phase, of plants growing in the Botanical Garden of Lisbon showed marked differences in their composition. The composition of the oil isolated from flowers was dominated by linalyl acetate while in that one from leaves, 1,8-cineole was the major compound.

In the present work, we report the results of the qualitative and quantitative analyses of the essential oils of representative samples of four spontaneous populations of $T$. lotocephalus and one of T. $\times$ mourae, performed by $\mathrm{GC}$ and $\mathrm{GC}-$ mass spectrometry. Occasionally, analysis of the total essential oil by ${ }^{13} \mathrm{C}-\mathrm{NMR}$ was also used to confirm the identity of the major volatile constituents. On the other hand, the oil of several individual plants of three populations of $T$. lotocephalus was also analysed mainly by GC and the results were submitted to Chemometric Cluster and Principal Components analyses, in order to study its infraspecific variability.

\section{Material and methods}

\subsection{Plant material}

Aerial parts of T. lotocephalus G. López and R. Morales and T. × mourae Paiva and Salgueiro (Lamiaceae) were collected at flowering stage, in May-June 1993, in SE Algarve. Four representative samples of $T$. lotocephalus from different localities were 
collected: Ludo (A), Amendoeira (B), Quinta de Marim (C) and Malhão-Amendoeira (D). T. $\times$ mourae grows only in Quinta de Marim (E), where one representative population sample was collected to perform the qualitative and quantitative analysis of the essential oil. Voucher specimens were deposited in the Herbarium of the Botanical Institute of the University of Coimbra (COI).

In order to study the infraspecific variability of the essential oils of T. lotocephalus, 37 individual plants from populations $\mathrm{A}-\mathrm{C}$ were also collected at the same time as homogeneous samples of the corresponding populations. As T. $\times$ mourae is a very rare plant only three individual plants were available for this study.

\subsection{Analysis of the essential oils}

The essential oil yield of the air-dried plant material was determined according to the European Pharmacopoeia method (Conseil de l'Europe, 1983). Analysis of volatile oils obtained by hydrodistillation were carried out by GC and GC-MS on two fused-silica capillary columns with stationary phases of different polarities (Carboxaw 20M and methylsilicone SE-30), as previously described (Salgueiro et al., 1995; Adzet et al., 1989). ${ }^{13} \mathrm{C}$-NMR spectra were recorded at $50 \mathrm{MHz}$, in $\mathrm{CDCl}_{3}$, using TMS as internal standard.

Identification of components was made on the basis of their retention indices in relation to an homologous series of fatty acid Me esters and mass spectra, which were compared with those of our own library, literature data and authentic samples. When necessary, analysis of the total essential oil by ${ }^{13} \mathrm{C}-\mathrm{NMR}$ was also used to confirm the identity of compounds with a percentage higher than $1 \%$, as previously reported (Salgueiro et. al., 1995; Tomi et al., 1995).

The percentage composition of the essential oils was computed from the GC peak areas on the two columns, without using correction factors.

\subsection{Infraspecific variability}

The essential oil of each individual plant of T. lotocephalus was analysed by GC and, when necessary, by GC-MS and ${ }^{13} \mathrm{C}-\mathrm{NMR}$ using the same analytical conditions indicated above. From all the volatile constituents, those which showed a percentage equal or higher than $2 \%$ were selected to be included in the multivariate analysis (Principal Component Analysis and Cluster Analysis) using PARVUS (Forina et al., 1988) and ESTATS (Tomàs et al., 1988) chemometric software packages, as previously reported (Salgueiro et al., 1995). Selected constituents (30) are shown in Table 1.

\section{Results and discussion}

The average yields of the essential oil of the air-dried aerial parts of the representative samples of $T$. lotocephalus and $T$. $\times$ mourae were 1.1 and $1 \%(\mathrm{v} / \mathrm{w})$, respectively. Quantitative and qualitative analytical results are shown in Table 1, where the compounds are listed in order of their elution on a carbowax $20 \mathrm{M}$ column. More 
Table 1

Constituents of essential oils of Portuguese populations of Thymus lotocephalus and Thymus $\times$ mourae

\begin{tabular}{|c|c|c|c|c|c|}
\hline \multirow[t]{3}{*}{ Components $^{\mathrm{a}}$} & \multicolumn{5}{|c|}{$\%$ in essential oil of populations } \\
\hline & \multicolumn{4}{|c|}{ T. lotocephalus } & \multirow{2}{*}{$\frac{T . \times \text { mourae }}{\mathrm{E}}$} \\
\hline & A & $\mathrm{B}$ & $\mathrm{C}$ & $\mathrm{D}$ & \\
\hline Tricyclene & 0.1 & 0.2 & 0.2 & 0.2 & 0.1 \\
\hline$\alpha$-Thuyene & 0.2 & 0.4 & 0.3 & 0.5 & 0.1 \\
\hline$\alpha$-Pinene $^{\mathrm{b}}$ & 6.0 & 5.8 & 5.0 & 9.0 & 2.2 \\
\hline Camphene $^{\mathrm{b}}$ & 1.9 & 0.8 & 1.5 & 1.3 & 3.9 \\
\hline$\beta$-Pinene ${ }^{\mathrm{b}}$ & 1.0 & 0.5 & 0.7 & 0.7 & 1.4 \\
\hline Sabinene $^{\mathrm{b}}$ & 2.3 & 1.9 & 1.1 & 2.0 & 1.0 \\
\hline Myrcene & 0.5 & 0.5 & 0.4 & 0.6 & 0.6 \\
\hline$\alpha$-Phellandrene & $\mathrm{t}$ & $\mathrm{t}$ & $\mathrm{t}$ & - & $\mathrm{t}$ \\
\hline$\alpha$-Terpinene & 0.1 & 0.2 & 0.1 & 0.2 & 0.1 \\
\hline Limonene $^{\mathrm{b}}$ & 1.2 & 1.2 & 1.2 & 2.0 & 0.4 \\
\hline 1,8-Cineole ${ }^{\mathrm{b}}$ & 12.2 & 11.8 & 6.9 & 12.7 & 23.5 \\
\hline cis- $\beta$-Ocimene & $\mathrm{t}$ & $\mathrm{t}$ & $\mathrm{t}$ & $\mathrm{t}$ & $\mathrm{t}$ \\
\hline trans- $\beta$-Ocimene & $\mathrm{t}$ & $\mathrm{t}$ & $\mathrm{t}$ & $\mathrm{t}$ & $\mathrm{t}$ \\
\hline$\gamma$-Terpinene & 0.9 & 1.0 & 0.9 & 1.1 & 1.4 \\
\hline$p$-Cymene & 1.3 & 1.2 & 0.5 & 0.9 & 0.7 \\
\hline Terpinolene & 0.1 & 0.1 & 0.1 & 0.2 & 0.1 \\
\hline 1-Octen-3-yl acetate & 0.1 & 0.1 & $\mathrm{t}$ & 0.1 & - \\
\hline 1-Octen-3-ol & $\mathrm{t}$ & $\mathrm{t}$ & $\mathrm{t}$ & $\mathrm{t}$ & - \\
\hline Nonanal & $\mathrm{t}$ & - & $\mathrm{t}$ & $\mathrm{t}$ & - \\
\hline Fenchone & 0.1 & 0.1 & 0.1 & $\mathrm{t}$ & - \\
\hline Hexyl butyrate & 0.1 & $\mathrm{t}$ & $\mathrm{t}$ & $\mathrm{t}$ & $\mathrm{t}$ \\
\hline Hexyl-2-methylbutyrate & $\mathrm{t}$ & $\mathrm{t}$ & $\mathrm{t}$ & $\mathrm{t}$ & $\mathrm{t}$ \\
\hline cis-Linalool oxide & 0.5 & 0.4 & 0.2 & 0.3 & 0.1 \\
\hline$\alpha-p$-Dimethylstyrene & $\mathrm{t}$ & $\mathrm{t}$ & $\mathrm{t}$ & $\mathrm{t}$ & - \\
\hline trans-Sabinene hydrate ${ }^{\mathrm{b}}$ & 3.0 & 0.9 & 0.5 & 0.9 & 0.2 \\
\hline trans- Linalool oxide & 0.2 & 0.2 & 0.1 & 0.1 & 0.1 \\
\hline Nerol oxide & 0.1 & $\mathrm{t}$ & $\mathrm{t}$ & $\mathrm{t}$ & - \\
\hline Campholenal & 0.3 & 0.2 & 0.1 & 0.1 & $\mathrm{t}$ \\
\hline$\beta$-Bourbonene & 0.1 & $\mathrm{t}$ & $\mathrm{t}$ & $\mathrm{t}$ & $\mathrm{t}$ \\
\hline Camphor ${ }^{\mathrm{b}}$ & 4.6 & 4.7 & 6.5 & 5.6 & 9.0 \\
\hline Linalool $^{\mathrm{b}}$ & 16.5 & 9.5 & 3.7 & 6.8 & 4.7 \\
\hline cis- Sabinene hydrate & 0.2 & 0.1 & 0.1 & 0.2 & 0.2 \\
\hline$\alpha$-Gurjunene & 0.1 & $\mathrm{t}$ & $\mathrm{t}$ & $\mathrm{t}$ & $\mathrm{t}$ \\
\hline Linalyl acetate ${ }^{\mathrm{b}}$ & 3.0 & 0.1 & 0.2 & 0.3 & $\mathrm{t}$ \\
\hline Pinocarvone & 0.3 & 0.2 & 0.2 & 0.1 & 0.1 \\
\hline Bornyl formate & $\mathrm{t}$ & $\mathrm{t}$ & $\mathrm{t}$ & 0.1 & 0.1 \\
\hline Bornyl acetate ${ }^{\mathrm{b}}$ & 2.3 & 0.5 & 0.9 & 0.5 & 0.7 \\
\hline$\beta$-Elemene & $\mathrm{t}$ & $\mathrm{t}$ & - & $\mathrm{t}$ & - \\
\hline trans- $\alpha$-Bergamotene & $\mathrm{t}$ & $\mathrm{t}$ & $\mathrm{t}$ & $\mathrm{t}$ & - \\
\hline Terpinen-4-ol ${ }^{\mathrm{b}}$ & 2.8 & 3.9 & 0.9 & 2.1 & 1.4 \\
\hline$\beta$-Caryophyllene ${ }^{\mathrm{b}}$ & 1.2 & 0.9 & 2.0 & 1.6 & 4.8 \\
\hline Myrtenal & 0.3 & 0.4 & 0.3 & 0.1 & - \\
\hline allo-Aromadendrene $\mathrm{e}^{\mathrm{b}}$ & 0.3 & 1.5 & 1.0 & 1.7 & 0.5 \\
\hline
\end{tabular}


Table 1 - continued

Components $^{\mathrm{a}}$

$\%$ in essential oil of populations

\section{T. lotocephalus}

T. $\times$ mourae

$\begin{array}{llllll}\mathrm{A} & \mathrm{B} & \mathrm{C} & \mathrm{D} & \mathrm{E}\end{array}$

\begin{tabular}{|c|c|c|c|c|c|}
\hline cis-Verbenol & 0.7 & 1.2 & 0.8 & 1.2 & 0.2 \\
\hline trans-Pinocarveol & 0.1 & 0.1 & $\mathrm{t}$ & 0.1 & 0.1 \\
\hline$\delta$-Terpineol & 0.7 & 0.9 & 0.6 & 1.1 & 1.2 \\
\hline trans-Verbenol $^{\mathrm{b}}$ & 2.0 & 3.1 & 1.9 & 3.3 & 0.6 \\
\hline$\alpha$-Humulene & $\mathrm{t}$ & $\mathrm{t}$ & - & $\mathrm{t}$ & $\mathrm{t}$ \\
\hline$\beta$-Cubebene & $\mathrm{t}$ & 0.1 & $\mathrm{t}$ & $\mathrm{t}$ & $\mathrm{t}$ \\
\hline$\alpha$-Terpineol ${ }^{\mathrm{b}}$ & 1.7 & 1.8 & 0.8 & 1.2 & 2.2 \\
\hline$\alpha$-Terpinyl acetate ${ }^{b}$ & 0.2 & 0.2 & 0.1 & 0.1 & $\mathrm{t}$ \\
\hline Borneol $^{\mathrm{b}}$ & 3.8 & 2.4 & 3.2 & 2.1 & 14.7 \\
\hline$\gamma$-Muurolene & $\mathrm{t}$ & $\mathrm{t}$ & - & $\mathrm{t}$ & - \\
\hline Verbenone & 0.6 & 0.7 & 0.4 & 0.5 & 0.2 \\
\hline Germacrene- $^{\mathrm{b}}$ & 1.1 & 1.7 & 1.1 & 1.9 & 0.8 \\
\hline$\beta$-Bisabolene & $\mathrm{t}$ & 0.2 & 0.2 & 0.3 & $\mathrm{t}$ \\
\hline Geranial & $\mathrm{t}$ & 0.3 & 0.2 & 0.4 & $\mathrm{t}$ \\
\hline Bornyl isovalerate & $\mathrm{t}$ & $\mathrm{t}$ & - & $\mathrm{t}$ & - \\
\hline Carvone & 0.2 & 0.4 & 0.5 & 0.5 & 0.1 \\
\hline Bicyclogermacrene $^{\mathrm{b}}$ & 0.1 & 0.3 & 0.4 & 0.4 & $\mathrm{t}$ \\
\hline Decanol & - & - & - & - & $\mathrm{t}$ \\
\hline Geranyl acetate ${ }^{\mathrm{b}}$ & 0.2 & 5.8 & 15.0 & 3.5 & 0.5 \\
\hline Citronellol & - & - & - & - & 0.3 \\
\hline$\delta$-Cadinene & 0.2 & 0.2 & 0.3 & 0.1 & $\mathrm{t}$ \\
\hline$\gamma$-Cadinene & $\mathrm{t}$ & $\mathrm{t}$ & 0.1 & $\mathrm{t}$ & $\mathrm{t}$ \\
\hline Myrtenol & 0.2 & 0.4 & 0.2 & 0.3 & 0.2 \\
\hline Cuminic aldehyde & $\mathrm{t}$ & - & - & $\mathrm{t}$ & 一 \\
\hline Geranyl isobutyrate & - & 0.1 & 0.1 & 0.1 & $\mathrm{t}$ \\
\hline Geranyl propionate & $\mathrm{t}$ & 0.1 & 0.2 & 0.1 & $\mathrm{t}$ \\
\hline trans-Carveol & 0.4 & 0.6 & 0.6 & 1.0 & 0.1 \\
\hline Cuparene & 0.1 & 0.3 & 0.4 & 0.2 & 0.2 \\
\hline Geraniol $^{\mathrm{b}}$ & 0.1 & 0.2 & 0.6 & 0.3 & $\mathrm{t}$ \\
\hline p-Cymen-8-ol & 0.4 & 0.9 & 0.3 & 0.4 & 0.2 \\
\hline Geranyl butyrate & $\mathrm{t}$ & 0.2 & 0.4 & 0.1 & 0.1 \\
\hline Geranyl isovalerate & - & - & - & - & 0.1 \\
\hline Geranyl isobutyrate & - & 0.1 & 0.2 & 0.1 & - \\
\hline Isocaryophyllene oxide & 0.6 & 0.3 & 0.4 & 0.2 & 0.3 \\
\hline$\beta$-Caryophyllene oxide ${ }^{\mathrm{b}}$ & 5.9 & 3.5 & 3.6 & 3.8 & 3.5 \\
\hline Ledol $^{\text {b }}$ & 1.4 & 3.0 & 2.9 & 3.4 & 1.9 \\
\hline Cubenol $^{\mathrm{b}}$ & 0.3 & 1.2 & 0.9 & 1.5 & 0.4 \\
\hline Globulol & 0.4 & 1.0 & 1.0 & 1.0 & 0.1 \\
\hline Viridiflorol $^{\mathrm{b}}$ & 2.2 & 6.5 & 7.0 & 6.4 & 0.9 \\
\hline Cuminic alcohol & 0.2 & 0.4 & 0.1 & 0.2 & $\mathrm{t}$ \\
\hline 10-epi- $\gamma$-Eudesmol & - & $\mathrm{t}$ & $\mathrm{t}$ & $\mathrm{t}$ & 一 \\
\hline Spathulenol ${ }^{\mathrm{b}}$ & 1.2 & 1.1 & 1.0 & 1.0 & 0.2 \\
\hline Eugenol & $\mathrm{t}$ & $\mathrm{t}$ & - & $\mathrm{t}$ & - \\
\hline T-Cadinol ${ }^{\mathrm{b}}$ & 0.1 & 0.2 & 0.1 & 0.3 & 0.1 \\
\hline
\end{tabular}


Table 1 -continued

Components $^{\mathrm{a}}$

$\%$ in essential oil of populations

\section{T. lotocephalus}

T. $\times$ mourae

A

B

$\mathrm{C}$

D

$\mathrm{E}$

10-epi-Cadinol

Thymol

$\alpha$-Cadinol ${ }^{\mathrm{b}}$

Intermedeol $^{\mathrm{b}}$

Eugenyl acetate

Monoterpene hydrocarbons

Oxygenated monoterpenes

Sesquiterpene hydrocarbons

Oxygenated sesquiterpenes

Others

Total identified

$\begin{array}{ll}\mathrm{t} & 0.1 \\ \mathrm{t} & \mathrm{t} \\ 0.4 & 0.4 \\ 3.5 & 1.0 \\ 0.3 & 1.1\end{array}$

15.7

58.1

3.4

16.1

0.6

93.9

13.9
53.0
5.4
18.4
1.3

$\mathrm{t}$
$\overline{0}$
9.3
0.8

0.1

-

1.0

0.2

1.1

$\begin{array}{rrr}12.1 & 18.8 & 12.1 \\ 47.0 & 46.6 & 61.1 \\ 5.7 & 6.5 & 6.6 \\ 26.7 & 18.9 & 15.0 \\ 0.9 & 1.4 & 0.3\end{array}$

92.4

92.2

$\mathrm{t}$ : traces $\leqslant 0.05 \%$

${ }^{\mathrm{a}}$ Components are listed in order of their elution from a Carbowax 20M column.

${ }^{\mathrm{b}}$ Constituents selected for the multivariate analysis.

than $92 \%$ of the volatile oil was identified in each sample and in total 92 components were identified.

Oxygenated monoterpenes were shown to be the main group of constituents in all samples (46.6-61.1\%). 1,8-Cineole was an important constituent in the essential oil of the four populations investigated from $T$. lotocephalus (6.9-12.7\%). Nevertheless, important differences between other main components were found, particulary linalool (3.7-16.5\%) and geranyl acetate $(0.2-15.0 \%)$, which were the major compounds of populations A and C, respectively. These results showed some important differences between the populations, even between those from relatively close localities. All samples were also characterized by a high percentage of oxygenated sesquiterpenes (16.1-26.7\%), some of which showing some variability, mainly intermedeol $(0.2-9.5 \%)$. This compound was previously found by us in the essential oil of $T$. camphoratus, another endemic taxon from Portugal (Salgueiro et al., 1997b) and reported for the first time in Lamiaceae.

The main components of the oil of T. $\times$ mourae were 1,8 -cineole $(23.5 \%)$ and borneol $(14.7 \%)$. Among sesquiterpenes, the oxygenated ones were detected in higher concentrations than the hydrocarbonated, being intermedeol $(7.5 \%)$ the major one. As $T$. $\times$ mourae is a natural hybrid of $T$. lotocephalus and T. mastichina subsp. donyanae, with intermediate morphological features of its parental species, it was not surprising to find compounds of both parents in its essential oil. So, borneol comes from $T$. mastichina subsp. donyanae (Salgueiro et al., 1997c), 1,8-cineole from both parents and a high percentage of oxygenated sesquiterpenes, particulary intermedeol, from $T$. lotocephalus. 


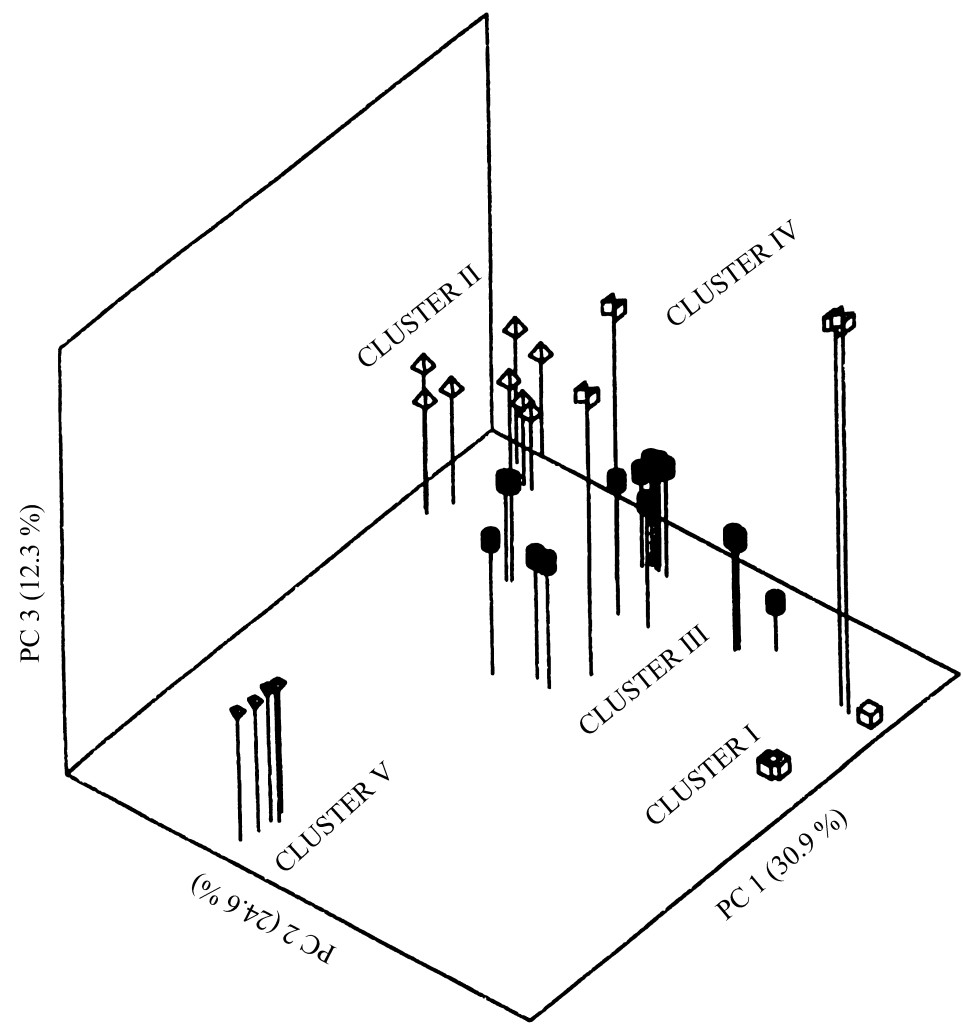

Fig. 1. Relative position of individuals of $T$. lotocephalus in the space defined by the first three principal components.

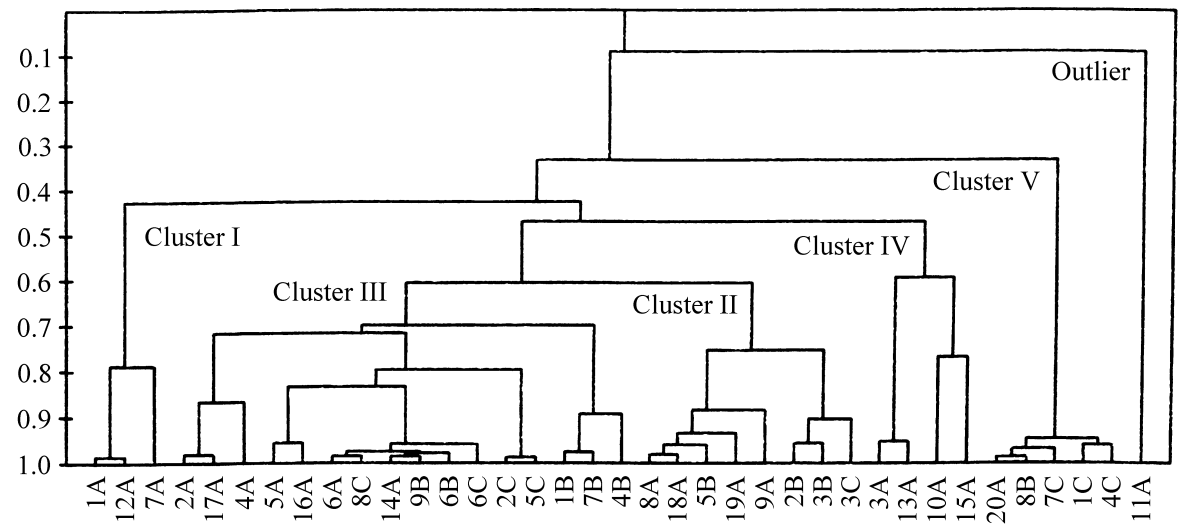

Fig. 2. Two-dimensional dendrogram obtained by Cluster Analysis of individual plants of T. lotocephalus. Horizontal: samples analysed (A, B and C indicate the population to which each sample belongs). Vertical: similarity levels between samples. 


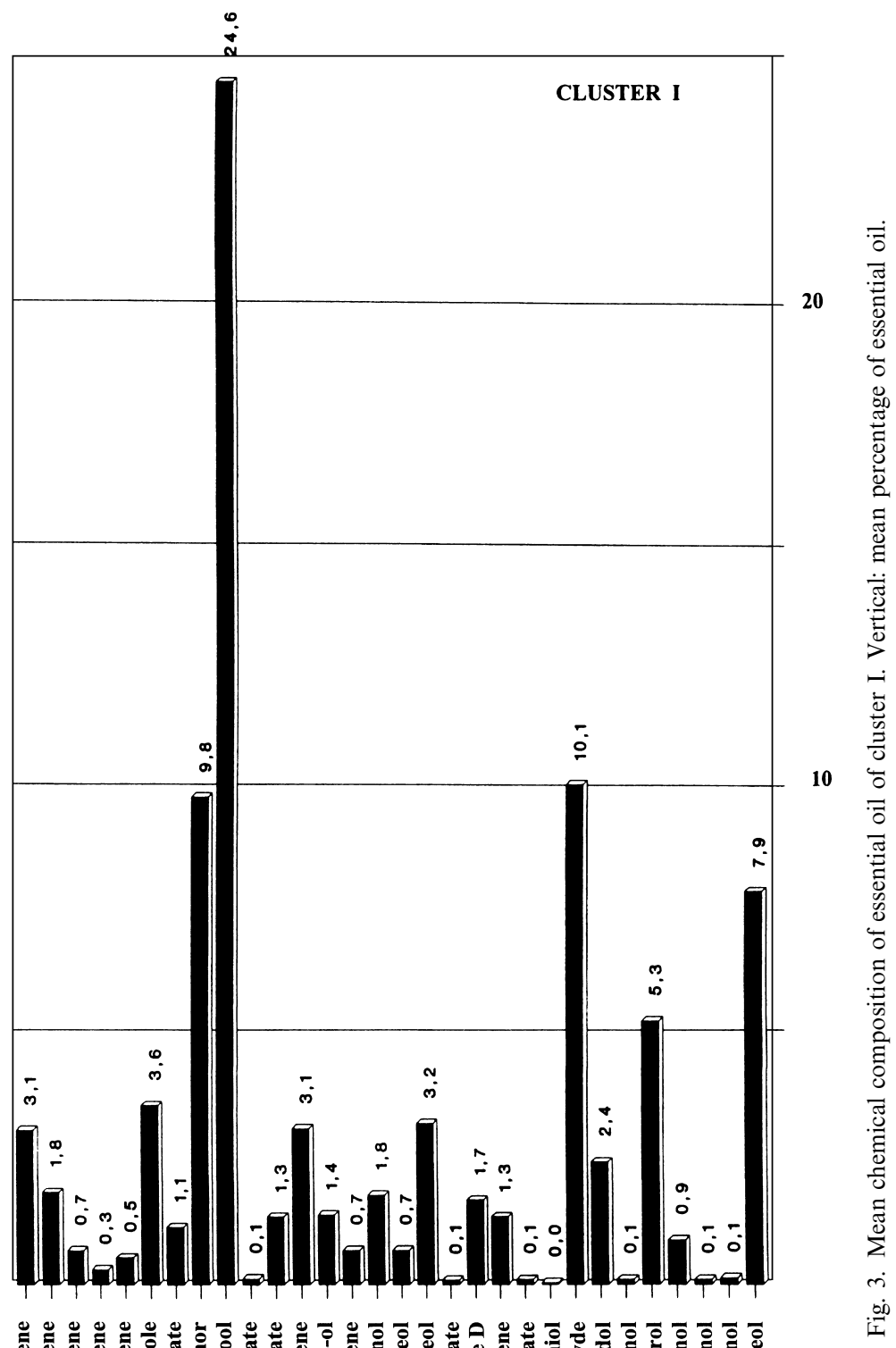




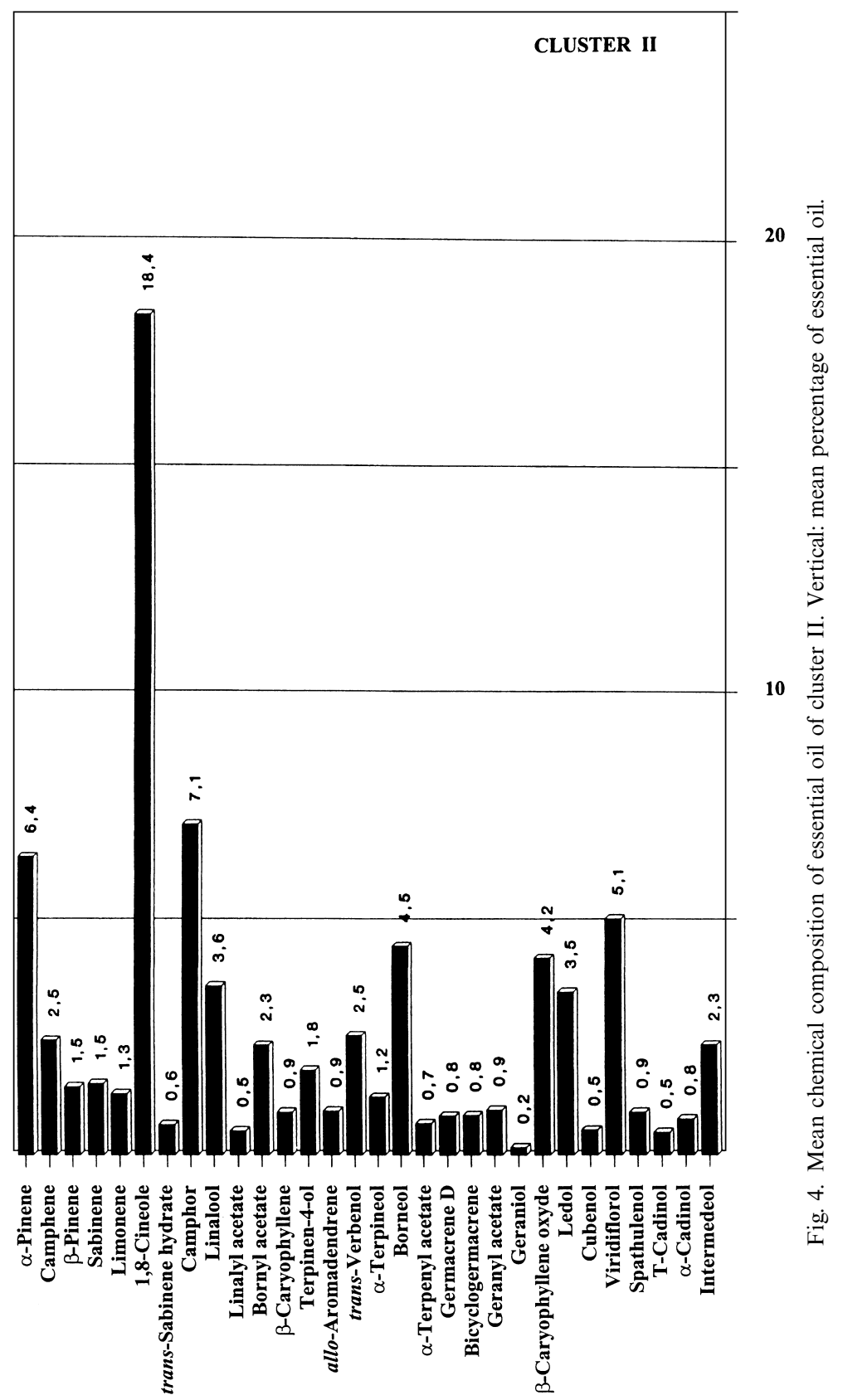




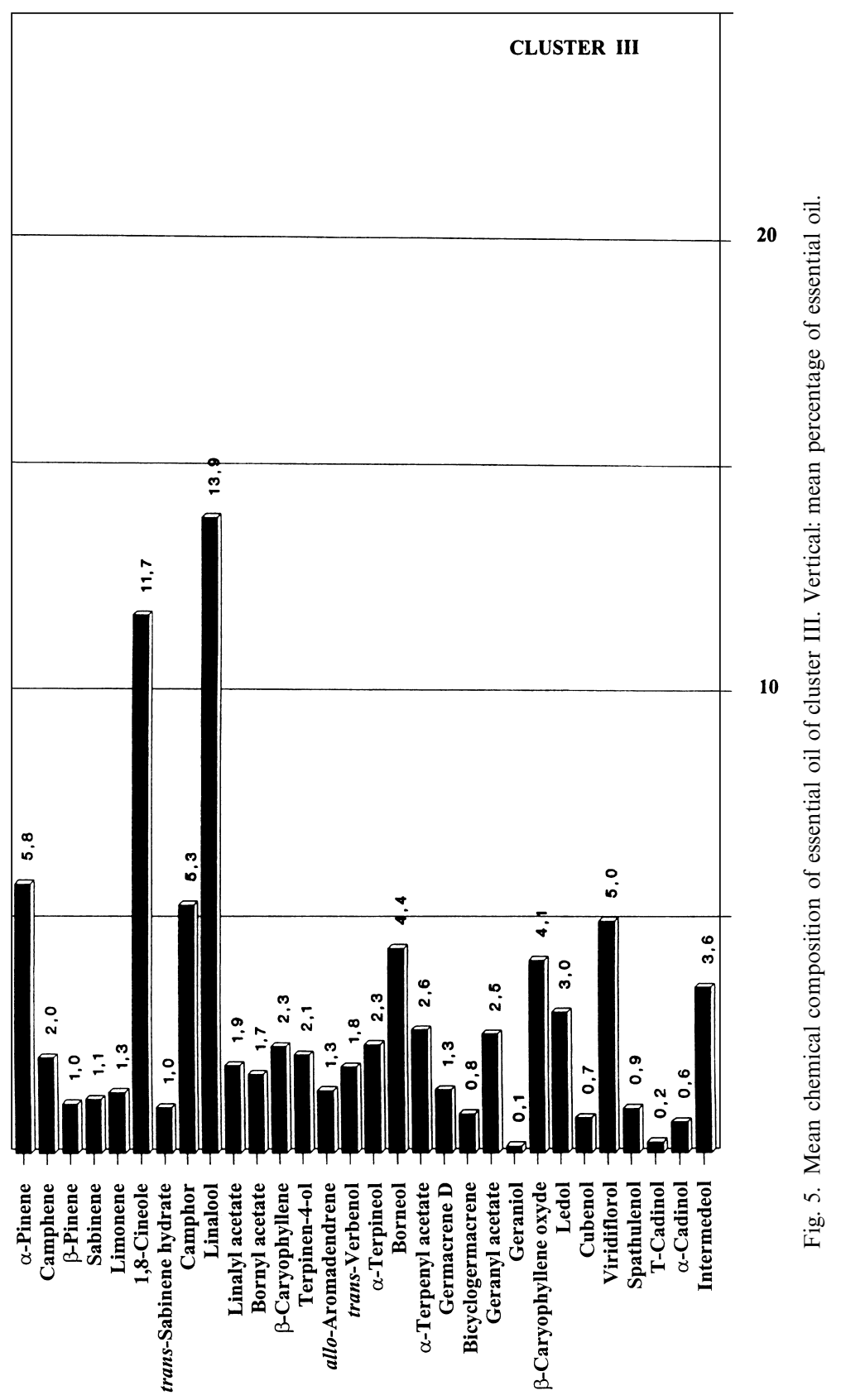




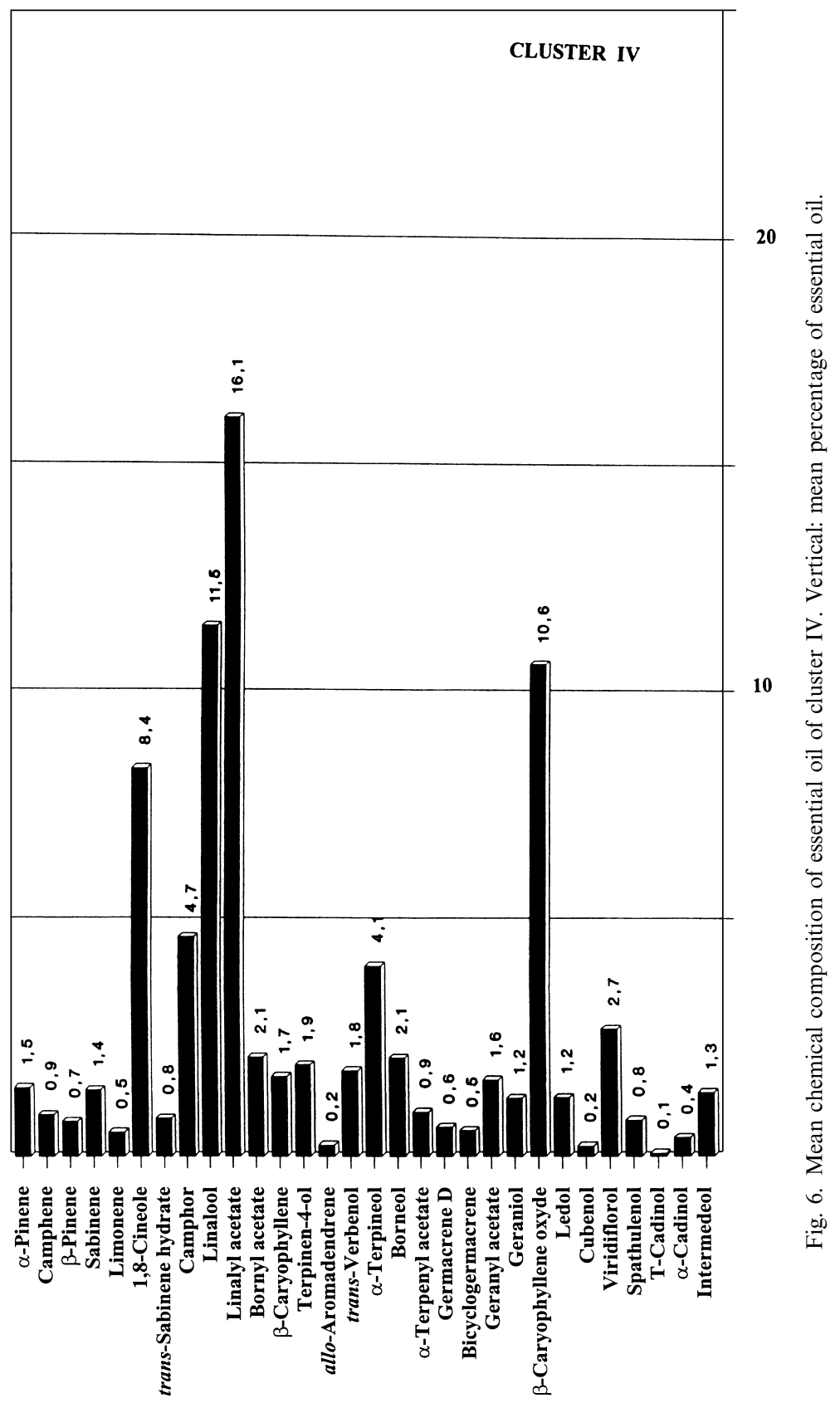




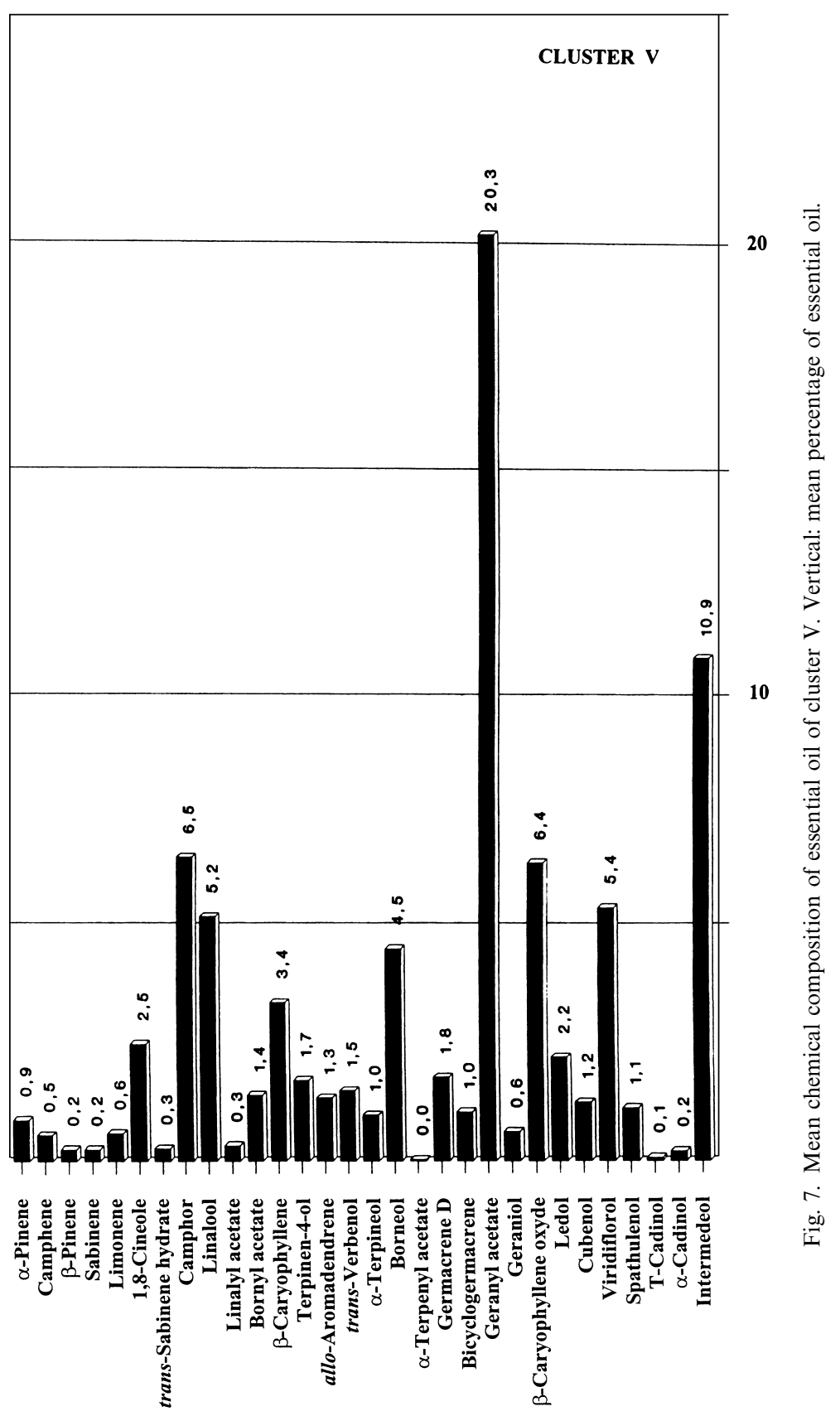


Table 2

Percentages of individuals of each locality belonging to each cluster

Cluster

\begin{tabular}{lrccccr}
\hline Population & N & I & II & III & IV & V \\
\hline A & 20 & 15.8 & 21.1 & 36.8 & 21.1 & 5.2 \\
B & 9 & - & 33.3 & 55.6 & - & 11.1 \\
C & 8 & - & 12.5 & 50.0 & - & 37.5 \\
\hline
\end{tabular}

The application of multivariate analysis to the results obtained of the volatile oils from individual plants of $T$. lotocephalus allow us to establish five different types of essential oils, which were differentiated by both the Cluster Analysis and PCA (Figs. 1 and 2, respectively): Cluster I, characterized by a high content of linalool ( $8.3 \%$ of the samples analysed); Cluster II, in which 1,8-cineole was the main constituent ( $22.2 \%$ of the samples analysed); Cluster III, which shows an intermediate composition between clusters I and II, its main constituents being linalool and 1,8-cineole ( $44.5 \%$ of the samples analysed); Cluster IV, characterized by a high content of linalyl acetate and linalool (11.1\% of the samples analysed); Cluster V, with substantial percentages of geranyl acetate ( $13.9 \%$ of the samples analysed). In the essential oils of Cluster I, linalool was the major constituent while linalyl acetate attained only $0.2 \%$. On the other hand, in Cluster IV, linalyl acetate was the main compound, followed by linalool. These two clusters showed, among the sesquiterpenes, a high concentration of $\beta$-caryophyllene oxide. Meanwhile, intermedeol was abundant only in Cluster I. This compound was also important in Cluster V. The average percentage composition of each cluster is showed in Figs. 3-7.

Table 2 shows the percentages of essential oil of each type found in every locality. These results showed a high infraspecific variability within the essential oils from plants collected in the same stage of development in spite of the small size of the populations. Even so, we found the five types of essential oils in the same population, as, for instance, in population A. This fact indicates that the chemical polymorphism of the essential oil of $T$. lotocephalus might be due, in part, to genetic characters.

The essential oils of the individual plants of $T$. $\times$ mourae were characterized by their 1,8-cineole and borneol high content, which is in accordance with the results found in the analysis of the representative sample of this population. As we have studied only three individual samples it was not possible to conclude whether this taxon is or not chemopolymorphic. More plant material is necessary, but in order to protect the small and rare population of this hybrid, we did not collect large amount of plants. Nevertheless, we are look forward to find more populations for further research.

\section{Acknowledgements}

The authors are grateful to Professor Dr. Joseph Casanova and to Dr. Felix Tomi (University of Corsica) for providing ${ }^{13} \mathrm{C}$-NMR spectra. 


\section{References}

Adzet, T., Vila, R., Cañigueral, S., Ibáñez, C., 1989. The herb essential oil of Thymus glandulosus Lag. ex H. del Vilar. Flav. Frag. J. 4, 133-134.

Conseil de l'Europe, 1983. Pharmacopée Européenne, Vol. 1. Maisonneuve S. A., Sainte Ruffine.

Figueiredo, A.C., Barroso, J.G., Pedro, L.G., Pais, M.S., Scheffer, J.J.C., 1993. The essential oils of two endemic portuguese thyme species: Thymus capitellatus Hoffmanns. and Link and Thymus lotocephalus G. López, R. Morales. Flav. Frag. J. 8, 53-57.

Forina, M., Leardi, R., Armanino, C., Lanteri, S., 1988. PARVUS: an Extendable Package of Programs for Data Exploration. Elsevier, Amsterdam.

Paiva, J., Salgueiro, L.R., 1994. Novedades corológicas, taxonómicas y nomenclaturales de tomillos portugueses. Anal. Jard. Bot. Madrid 52, 114-117.

Proença da Cunha, A., Salgueiro, L.R., 1991. The chemical polymorphism of Thymus zygis ssp. sylvestris from central Portugal. J. Essent. Oils Res. 3, 409-412.

Salgueiro, L.R., 1992. Essential oils of endemic Thymus species from Portugal. Flav. Fragr. J. 7, 159-162.

Salgueiro, L.R., Proença da Cunha, A., Paiva, J., 1993. Chemotaxonomic characterization of a Thymus hybrid from Portugal. Flav. Frag. J. 8, 325-330.

Salgueiro, L.R., Vila, R., Tomàs, X., Tomi, F., Cañigueral, S., Casanova, J., Proença da Cunha, A., Adzet, T., 1995. Chemical polymorphism of the essential oil of Thymus carnosus from Portugal. Phytochemistry 38, 391-396.

Salgueiro, L.R., Vila, R., Tomàs, X., Cañigueral, S., Proença da Cunha, A., Adzet, T., 1997a. Essential oil of Thymus villosus subsp. villosus and its chemical polymorphism. Flavour Fragr. J. 12, 117-122.

Salgueiro, L.R., Vila, R., Tomi, F., Tomàs, X., Cañigueral, S., Casanova, J., Proença da Cunha, A., Adzet, T., 1997b. Composition and infraspecific variability of essential oil from Thymus camphoratus. Phytochemistry. 45, 1177-1183.

Salgueiro, L.R., Vila, R., Tomàs, X., Cañigueral, S., Proença da Cunha, A., Adzet, T., 1997c. Composition and variability of the essential oils of Thymus species from section Mastichina from Portugal. Biochemical Systematics and Ecology. 25, 659-672.

Stahl-Biskup, E., 1991. The chemical composition of Thymus oils: a review of the literature 1960-1989. J. Essent. Oils Res. 3, 61-82.

Tomàs, X., Obiols, J., Sol, A., 1988. Application of pattern recognition to speciation data of heavy metals in suspended particulates of urban air. J. Chemometrics 3, 139-150.

Tomi, F., Bradesi, P., Bighelli, A., Casanova, J., 1995. Computer-aided identification of individual components of essential oils using Carbon-13 NMR spectroscopy. J. Magnetic Resonance Analysis 1, 25-34. 